\title{
Effect of sintering parameters using the central composite design method, electronic structure and physical properties of yttria-partially stabilized $\mathrm{ZrO}_{2}$ commercial ceramics
}

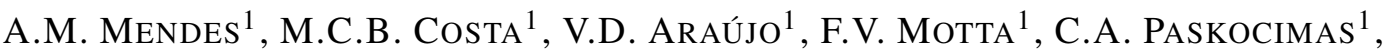 \\ W. ACCHAR ${ }^{2}$, E. LONGO $^{3}$, M.R.D. BOMIO ${ }^{1}$, L.S. CAVALCANTE ${ }^{4, *}$ \\ ${ }^{1}$ LSQM-Laboratório de Síntese Química de Materiais-DEMat, Universidade Federal do Rio Grande do Norte-UFRN, \\ P.O. Box 1524, 59078-970, Natal, RN, Brazil \\ ${ }^{2}$ Departamento de Física, Universidade Federal do Rio Grande do Norte-UFRN, \\ P.O. Box 1524, 59078-970, Natal, RN, Brazil \\ ${ }^{3}$ LIEC, Departamento de Química-Universidade Federal de Săo Carlos-UFSCar, \\ P.O. Box 676, 13565-905, Săo Carlos, SP, Brazil \\ ${ }^{4}$ PPGQ-DQ-CCN-GERATEC-Universidade Estadual do Piauí, Joăo Cabral, N. 2231, \\ P.O. Box 381, 64002-150 Teresina, PI, Brazil
}

\begin{abstract}
In this work, the effect of sintering parameters on electronic structure and physical properties of yttria-partially stabilized $\mathrm{ZrO}_{2}$ (YPSZ) commercial ceramics has been studied using the central composite design (CCD) method. The CCD method allows using empirical modelling with better fitting, by considering the interaction between both factors. Different temperature ranges and sintering times for processing of YPSZ ceramics have been used in order to evaluate the grain growth, hardness and volumetric shrinkage by the CCD method. X-ray diffraction patterns and Rietveld refinement data indicate that non-sintered YPSZ ceramics exhibits two phases related to tetragonal and monoclinic structures, while the sintered YPSZ ceramics exhibits a single phase related to a tetragonal structure. Moreover, the monoclinic structure presents zirconium $(\mathrm{Zr})$ atoms coordinated to seven oxygen $(\mathrm{O})$ atoms, while in the tetragonal structure $\mathrm{Zr}$ atoms are coordinated to eight $\mathrm{O}$ atoms. Field emission scanning electron microscopy images were employed to monitor the sintering and growth process. In addition, the response surfaces obtained from calculations presented the effect of thermal and kinetic variables on the physical properties such as average grain size, volumetric shrinkage and hardness of YPSZ ceramics.
\end{abstract}

Keywords: YPSZ ceramics; electronic structure; central composite design; hardness; shrinkage

(C) Wroclaw University of Science and Technology.

\section{Introduction}

Zirconium oxide $\left(\mathrm{ZrO}_{2}\right)$ is an important electronic ceramics with excellent mechanical properties [1]. However, due to its particular characteristics related to large volume change accompanying the structural transition from tetragonal to monoclinic, the sintering process necessary to formation of dense grains occurs only at high temperature [2]. Therefore, in the last years, several works based on yttrium-partially stabilized zirconia (YPSZ) ceramics have been carried out to improve the wear,

*E-mail: laeciosc@bol.com.br mechanical, electrical, cytotoxicity and bonding properties [3-9]. In particular, the use of $3 \mathrm{~mol} . \%$ yttrium oxide $\left(\mathrm{Y}_{2} \mathrm{O}_{3}\right)$ as a dopant in $\mathrm{ZrO}_{2}$ ceramics promotes the formation of an important commercial ceramics known as (3Y-PSZ). This ceramic material is characterized by high hardness and good toughness [10,11]. 3Y-PSZ ceramic powders present a significant fraction of monoclinic structure with a space group $\left(\mathrm{P} 2_{1} / \mathrm{c}\right)$ up to $1170{ }^{\circ} \mathrm{C}$. However, after sintering at $>1170{ }^{\circ} \mathrm{C}$, a metastable tetragonal structure with a space group $\left(\mathrm{P} 4_{2} / \mathrm{nmc}\right)$ is fully or partially stabilized at room temperature $[12,13]$. This structural transformation promotes a dilation in the lattice, resulting in cracks 
due to increase in grains size and volume from $4 \%$ to $5 \%$ which, in turn, induces compressive stress [14].

The modifications in the process of manufacturing and sintering of these ceramics enables the control over the structure and microstructure promoting an improvement in the electronic properties $[15,16]$. It is well known from the literature $[17,18]$, that the sintering temperature and time probably control the grain growth. However, the grain size above a critical value $(<0.8 \mu \mathrm{m})$ is not able to retain the tetragonal structure at room temperature, leading to a decrease in the mechanical properties $[19,20]$. In other words, unrestrained shrinkage of ceramics may lead to marginal accuracy and decreased strength of ceramic restorations [21, 22]. Moreover, the shrinkage characteristic in formation of necks between particles and its subsequent unification during the sintering process can be modeled dependent on variation in sintering temperature and time [23-25].

According to Faes et al. [26], previous investigations on the effect of microstructure on the performance of anodes for solid oxide fuel cells (SOFC) can be optimized using a statistical method called central composite design, enabling the optimization of their electronic properties by means of controlling the processing variables such as the fraction of $\mathrm{NiO} / \mathrm{YSZ}$ and the particle size of both. Therefore, the central composite design (CCD) method can be employed to response surface methodology (RSM) and also used in investigation of a system in order to establish a statistical model between the variables of interest and the factors that cause variations $[27,28]$. The design of experiments through the use of CCD method has received a great deal of attention in the literature in bioscience [29, 30], renewable energy [31, 32], and materials engineering [33-35]. Thus, this method is based on a detailed analysis of a system enabling observation of the response of a dependent variable by modifying the values of two or more independent variables simultaneously [36-39]. Therefore, this statistical approach for optimization of a system can reduce the number of experiments compared to the traditional trial and error method, providing the best combination of factors.

The present paper has as its aim to explore the grain size, hardness and volumetric shrinkage of 3Y-PSZ ceramics by creating a statistical model using the CCD method. Moreover, we explained in details the electronic structure by X-ray diffraction (XRD), Rietveld refinement, clusters modeling and electron density map of 3Y-PSZ ceramics. Field emission scanning electron microscopy (FESEM) was employed to verify the sintering and growth process of 3Y-PSZ ceramics. Finally, we described simultaneous influence of sintering temperature and time on the physical properties.

\section{Experimental}

\subsection{Statistical approach method}

The central composite design fits a quadratic model (second order) for a system with $\mathrm{k}$ controllable variables, each ranging between two levels (maximum and minimum) [40]. The number of runs by the CCD method is given by: $\left[2^{\mathrm{k}}+2 \mathrm{k}+\right.$ $\mathrm{n}_{\mathrm{c}}$ ], where $2^{\mathrm{k}}$ refers to the full factorial design, $2 \mathrm{k}$ are the axial points and $\mathrm{n}_{\mathrm{c}}$ are the central points (usually three to five points are used) [41].

The levels are expressed in the form of encoded variables ( \pm 1 for the factorial points, $\pm \alpha$ to the axial points, 0 (zero) to the center points). The value of $\alpha$ depends on the value of $k$ according to equation 1 [40]:

$$
\alpha=(2)^{k / 4}
$$

Equation 2 is a quadratic expression which correlates the factors and the responses of the system:

$$
\hat{y}=a_{0}+\sum_{i=1}^{k} a_{i} x_{i}+\sum_{i=1}^{k} a_{i i} x_{i}^{2}+\sum_{i=1}^{k} \sum_{j>1}^{k} a_{i j} x_{i} x_{j}
$$

$$
\mathrm{i}=1,2,3, \ldots, \mathrm{k} ; \mathrm{j}=1,2,3, \ldots, \mathrm{k} ; \mathrm{i} \neq \mathrm{j}
$$

In this expression, $x$ is the response, $x_{i}$ and $x_{j}$ are the coded values of the factors; $a_{0}$ is a constant, $\mathrm{a}_{\mathrm{i}}, \mathrm{a}_{\mathrm{j}}$ and $\mathrm{a}_{\mathrm{ij}}$ are the linear, quadratic and interaction coefficients, respectively. The response surfaces can be plotted from the obtained equations. 


\subsection{Thermal processing}

Commercial 3Y-PSZ ceramics powders from Tosoh, Japan (99.9 \% purity) were used in this study. All samples were uniaxially pressed at $390 \mathrm{MPa}$ and then isostatically pressed at $150 \mathrm{MPa}$. Sintering was performed in air in a conventional furnace (EDG F1600-Sinter-10P). The heating rate was kept constant at $2{ }^{\circ} \mathrm{C} / \mathrm{min}$ for all samples.

The factors (temperature and time) were evaluated in two factorial levels $(-1$ and +1$)$, two axial levels $(-\alpha$ and $+\alpha \rightarrow-1.41$ and +1.41 , for $\mathrm{k}=2)$ and three central points $(0)$ used to estimate the experimental error. Thus, $2^{2}+2 \times 2+3=11$ (eleven) experiments were performed.

The levels for each factor were obtained as follows: the maximum capacity of our furnace was $1600{ }^{\circ} \mathrm{C}$, so we chose $1550{ }^{\circ} \mathrm{C}$ to represent the temperature level (+1). Studies by Badwal et al. [42] presented sintering at low temperature $\left(1350{ }^{\circ} \mathrm{C}\right.$ for $4 \mathrm{~h}$ ). Therefore, we decided to $1350{ }^{\circ} \mathrm{C}$ as the temperature level $(-1)$ and $4 \mathrm{~h}$ as the time level $(-1)$. Casellas et al. [43] presented the results for sintering of 3 Y-PSZ ceramics at $1650{ }^{\circ} \mathrm{C}$ for $10 \mathrm{~h}$. Thus, extrapolating this time value, we assumed $12 \mathrm{~h}$ as the time level $(+1)$. Temperature and time level $(0)$ are the average between levels $(-1)$ and $(+1)$. Levels $(-1.41)$ and $(+1.41)$ were obtained by extrapolation of the values shown above.

The software Statistica was used to provide the necessary combinations of the levels to achieve the CCD. These combinations are shown in Table 1 under coded and uncoded variables.

The experiments were performed for different combinations of the levels. In order to reduce the error caused by the experimental procedure, the order of experiments was randomized [40]. As it can be observed in Table 1, the presented data are in good agreement with previous results reported in the literature $[42,43]$.

\subsection{Structural characterization}

The commercial powder 3Y-PSZ and sintered bodies were structurally characterized by XRD using a XRD-7000 diffractometer (Shimadzu, Japan) with $\mathrm{CuK} \alpha$ radiation $(\lambda=1.5406 \AA)$ in the $2 \theta$ range from $20^{\circ}$ to $80^{\circ}$ at a scanning rate of $2^{\circ} \cdot \mathrm{min}^{-1}$ (exposure time of $30 \mathrm{~min}$ ). The Rietveld routines were performed in the $2 \theta$ range from $20^{\circ}$ to $80^{\circ}$ at a scanning rate of $1^{\circ} \cdot \mathrm{min}^{-1}$ (exposure time of $60 \mathrm{~min}$ ). The shapes and average grain sizes of 3Y-PSZ ceramics sintered bodies were observed by FE-SEM using a Supra 35-VP microscope (Carl Zeiss, Germany) operated at $10 \mathrm{kV}$. Vickers hardness investigation was performed according to ASTM C1327-08 [44]. Ten indents were made on each sample using a load of $0.5 \mathrm{kgf}$ for a holding time of $15 \mathrm{~s}$, each.

The volumetric shrinkage was calculated by equation 3:

$$
V S(\%)=\frac{\left(V_{i}-V_{f}\right)}{V_{i}} \times 100
$$

where VS (\%) represents the percentage of volumetric shrinkage, $\mathrm{V}_{\mathrm{i}}$ is the volume of the samples before sintering, $V_{f}$ is the volume after sintering. $\mathrm{V}_{\mathrm{i}}$ and $\mathrm{V}_{\mathrm{f}}$ were measured with a profile projector (PH-A14, Mitutoyo).

\section{Results and discussion}

\subsection{X-ray diffraction analysis}

Fig. 1 (I to XII) shows the XRD patterns of 3Y-PSZ ceramics: as received commercial powder or non-sintered ceramics and ceramics sintered at different temperatures and times, respectively.

As it can be noted, in Fig. 1a (I) and Fig. 1b, the 3Y-PSZ non-sintered and sintered ceramics reveal the presence of two phases related to tetragonal $(\bullet)$ and monoclinic $(\bullet)$ structures. The others samples illustrated in Fig. 1a (II to VIII) present some small peaks relating to the presence of residual $\mathrm{ZrO}_{2}$, corresponding to monoclinic structure, while in Fig. 1a (IX to XII) the presence of the phase related to monoclinic structure cannot be detected in the diffraction peaks. Moreover, the diffraction peaks can be used to evaluate the structural order at long range or periodicity of the material. The $\mathrm{ZrO}_{2}$ phases were confirmed by the comparison of the XRD patterns with the respective files of Inorganic Crystal Structure Database (ICDS) No. 18190 referring to monoclinic structure and files 
Table 1. Coded and uncoded values of levels for sintering temperature and time and its execution order.

\begin{tabular}{ccccc}
\hline \multirow{2}{*}{ 3Y-PSZ sintered ceramics } & \multicolumn{2}{c}{ Coded Levels } & \multicolumn{2}{c}{ Uncoded Levels } \\
\cline { 2 - 5 } & Temperature & time & Temperature $\left[{ }^{\circ} \mathrm{C}\right]$ & time $[\mathrm{h}]$ \\
\hline \hline VII & -1.41 & 0 & 1309 & 8 \\
XII & -1 & -1 & 1350 & 4 \\
X & -1 & 1 & 1350 & 12 \\
VIII & 0 & -1.41 & 1450 & 2.37 \\
VI & 0 & 0 & 1450 & 8 \\
II & 0 & 0 & 1450 & 8 \\
XI & 0 & 0 & 1450 & 8 \\
III & 0 & 1.41 & 1450 & 13.64 \\
IX & 1 & -1 & 1550 & 4 \\
IV & 1 & 1 & 1550 & 12 \\
V & 1.41 & 0 & 1591 & 8 \\
\hline
\end{tabular}

No. 66782 and No. 86603 referring to tetragonal structure [45-47]. Therefore, all the 3Y-PSZ nonsintered and sintered ceramics exhibited characteristic diffraction peaks corresponding to an ordered structure at a long range. In Fig. 1b, the 3Y-PSZ non-sintered ceramics exhibited characteristic diffraction peaks relating to the presence of two phases; the main phase with the highest percentage is ascribed to tetragonal structure and the second phase is related to monoclinic structure. However, it can be verified in Fig. 1c that the increase of temperature $\left(1550{ }^{\circ} \mathrm{C}\right)$ and time $(12 \mathrm{~h})$ promotes a raise in sintering and formation of monophasic $\mathrm{ZrO}_{2}$ ceramics with tetragonal structure, which can be indexed by both ICSD files No. 66782 or No. 86603 [46, 47]. Finally, in Fig. 1c, it is noted that all the diffraction peaks are in good agreement with those reported for monophasic $\mathrm{ZrO}_{2}$ in respect ICSD file No. 66782 [46].

\subsection{Rietveld refinement analysis}

To verify and confirm if the structures of 3Y-PSZ non-sintered and sintered ceramics are monoclinic and tetragonal, a structural refinement by the Rietveld method was performed. The Rietveld method is a least squares refinement procedure where the experimental step-scanned values are adapted to the calculated ones. The profiles are considered to be known, and a model for a crystal structure available [48]. This structural refinement method presents several advantages over conventional quantitative analysis methods. As the method uses a whole pattern fitting algorithm, all lines for each phase are explicitly considered, and even severely overlapped lines are usually not a problem. Thus, it is not necessary to decompose patterns into separate Bragg peaks, as is often the case for traditional methods. The use of all reflections in a pattern rather than just the strongest ones minimizes both the uncertainty in the derived weight fractions and the effects of preferred orientation, primary extinction, and nonlinear detection systems [49].

The experimental lattice parameters, unit cell volumes, length of the chemical bonds, and bond angles between $(\mathrm{O} 1-\mathrm{Zr}-\mathrm{O} 2)$ and $(\mathrm{O} 1-\mathrm{Zr}-\mathrm{O} 1)$ were obtained and calculated by the Rietveld refinement method [48] using the ReX Program version 0.8.0 [50]. The structural refinement results for 3 Y-PSZ non-sintered ceramics and ceramics sintered at $1550{ }^{\circ} \mathrm{C}$ for $12 \mathrm{~h}$ are illustrated in Fig. 2, and the refinement results are presented in Table 2.

The results obtained from the Rietveld refinement method show a good agreement between the observed XRD patterns and theoretical results (Fig. 2). Moreover, the profiles of XRD patterns experimentally observed and theoretically calculated display small, near zero, 


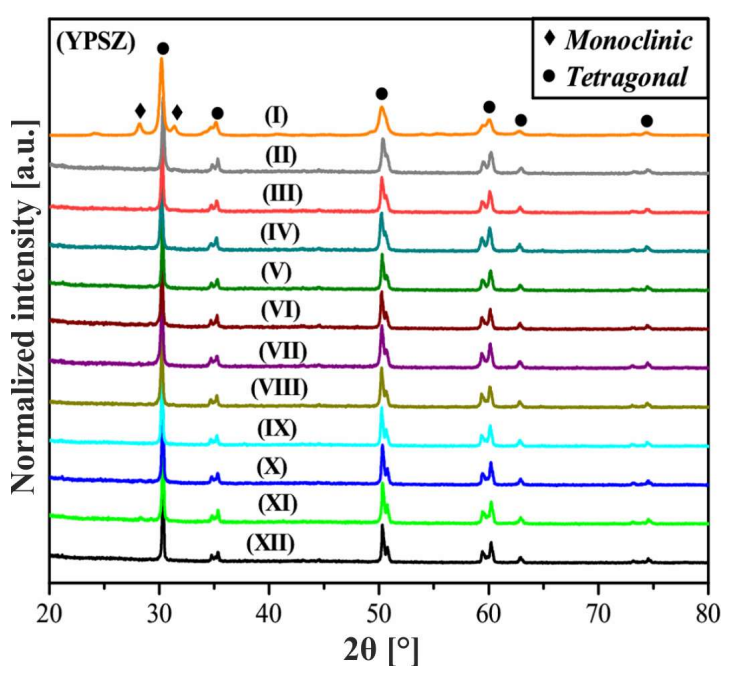

(a)

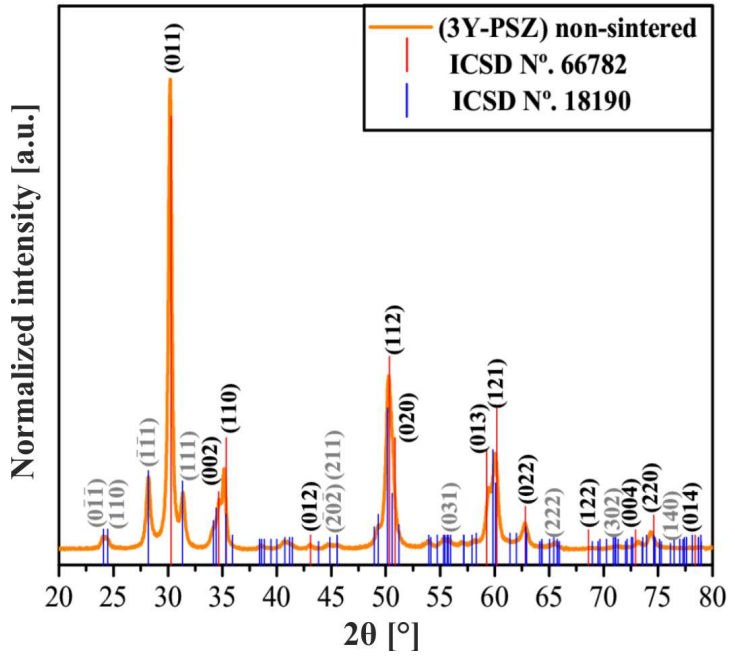

(b)

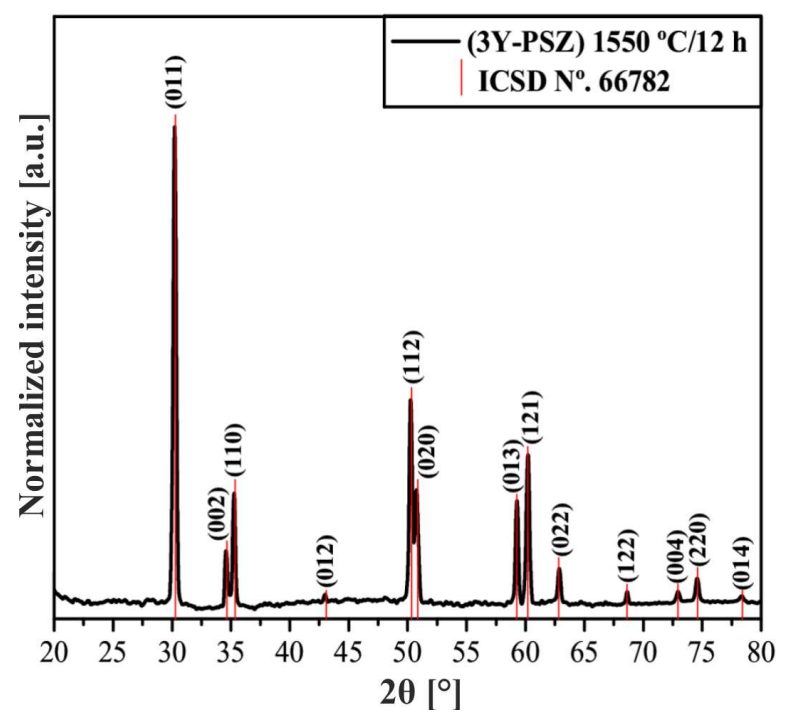

(c)

Fig. 1. (a) XRD patterns of 3Y-PSZ non-sintered ceramics (I) and 3Y-PSZ ceramics sintered at different temperatures (II to XII) and times, (b) Indexed monoclinic and tetragonal phases in XRD patterns of 3Y-PSZ ceramics. The vertical lines indicate the relative positions of the diffraction peaks described in ICSD No. 66782 and No. 18190 and (c) Indexed tetragonal phase XRD patterns for 3Y-PSZ ceramics sintered at $1550{ }^{\circ} \mathrm{C}$ for $12 \mathrm{~h}$, respectively.

differences on the intensity scale as illustrated by the $\left(\mathrm{Y}_{\text {Observed }}-\mathrm{Y}_{\text {Calculated }}\right)$ line. Fig. 2a shows the results of the Rietveld refinement obtained from a quantitative phase analysis with two monoclinic and tetragonal structures using a better approximation and indexing of the Crystallographic Information File (CIF) and employing two CIF files No. 18190 and No. 66782 [45, 46]. However, it is possible to observe the presence of singlephase related to tetragonal structure in Fig. $2 b$. This behavior is due to increased temperature and time of sintering of the 3Y-PSZ ceramics which was indexed with the CIF file No. 66782 [46].

The results in Table 2 obtained from the Rietveld refinement method indicate good 
Table 2. Rietveld refinement results for 3 Y-PSZ non-sintered ceramics and ceramics sintered at $1550{ }^{\circ} \mathrm{C}$ for $12 \mathrm{~h}$.

\begin{tabular}{|c|c|c|c|c|c|}
\hline Atoms & Wyckoff & Site & $\mathrm{x}$ & $\mathrm{y}$ & $\mathrm{Z}$ \\
\hline $\mathrm{Zr}$ & $4 e$ & 1 & 0.26977 & 0.03542 & 0.21178 \\
\hline $\mathrm{O} 1$ & $4 \mathrm{e}$ & 1 & 0.07287 & 0.34262 & 0.35167 \\
\hline $\mathrm{O} 2$ & $4 \mathrm{e}$ & 1 & 0.43843 & 0.76134 & 0.48151 \\
\hline $\mathrm{Zr}$ & $2 a$ & $-4 m 2$ & 0.75 & 0.25 & 0.25 \\
\hline $\mathrm{O} 1$ & $4 d$ & $2 \mathrm{~mm}$ & 0.25 & 0.25 & 0.46829 \\
\hline
\end{tabular}

[Phase 1: $\mathrm{ZrO}_{2} ; \mathrm{P} 21 / \mathrm{c}(14)-$ Monoclinic $(\mathrm{a}=5.18449(8), \mathrm{b}=$ $5.21618(4) \AA, c=5.32812(7) \AA ; \mathrm{V}=\mathrm{V}=142.22(3) \AA^{3} ; \beta=99.23(8)^{\circ}$ and $\mathrm{Z}=4)$ ] and [Phase $2: \mathrm{ZrO}_{2} ; \mathrm{P}_{2} / \mathrm{nmc}(137)-$ Tetragonal $(\mathrm{a}=\mathrm{b}=3.5792 \AA$, $\mathrm{c}=5.1782 \AA ; \mathrm{c} / \mathrm{a}=1, \mathrm{~V}=66.34 \AA^{3} ; \mathrm{Z}=2 \mathrm{]} ; \mathrm{R}_{\mathrm{p}}=6.785 \% ; \mathrm{R}_{\mathrm{wp}}=$ $11.835 \% ; \mathrm{R}_{\exp }=6.218 \% ; \chi^{2}=3.6214$ and $\mathrm{GoF}=1.903$. Weights of the phases in the $\mathrm{ZrO}_{2}$ Monoclinic $=49.17 \%$ and $\mathrm{ZrO}_{2}$ Tetragonal $=50.83 \%$.

\begin{tabular}{cccccc}
\hline $\mathrm{Zr}$ & $2 \mathrm{a}$ & $-4 \mathrm{~m} 2$ & 0.75 & 0.25 & 0.25 \\
$\mathrm{O} 1$ & $4 \mathrm{~d}$ & $2 \mathrm{~mm}$. & 0.25 & 0.25 & 0.44896 \\
\hline
\end{tabular}

[Monophasic for $\mathrm{ZrO}_{2} ; \mathrm{P}_{2} / \mathrm{nmc}(137)$ - Tetragonal $(\mathrm{a}=\mathrm{b}=3.5578(6) \AA$, $\left.\mathrm{c}=5.1559(1) \AA ; \mathrm{V}=65.26(2) \AA^{3} ; \mathrm{Z}=2\right) ; \mathrm{R}_{\mathrm{p}}=5.231 \% ; \mathrm{R}_{\mathrm{wp}}=10.124 \%$;

$\mathrm{R}_{\exp }=8.173 \% ; \chi^{2}=1.52364$ and $\mathrm{GoF}=1.238$.

agreement between the XRD patterns observed experimentally and calculated theoretically. According to the literature [51, 52], the quality of the data from structural refinement is generally controlled by $\mathrm{R}_{\text {values }}\left(\mathrm{R}_{\mathrm{p}}, \mathrm{R}_{\mathrm{exp}}, \mathrm{R}_{\mathrm{wp}}\right)$ and the goodness of fit $\left(\mathrm{GoF}=\mathrm{R}_{\mathrm{wp}} / \mathrm{R}_{\exp }\right)$.

\subsection{Representation of $\mathrm{ZrO}_{2}$ and $\mathbf{Y}_{0.03} \mathbf{Z r}_{0.97} \mathbf{O}_{2}$ unit cells from the Rietveld refinement data}

Fig. 3 illustrates the schematic representations of the monoclinic $\mathrm{ZrO}_{2}$ and tetragonal $\mathrm{ZrO}_{2}$ and $\mathrm{Y}_{0.03} \mathrm{Zr}_{0.97} \mathrm{O}_{2}$ unit cells performed from the Rietveld refinement data.

These unit cells were modeled through the Visualization for Electronic and Structural Analysis (VESTA) version 3.4.0 for 64-bit version of Windows 7 [53] by Rietveld refinement data (lattice parameters and atomic positions) (Table 2). The $\mathrm{ZrO}_{2}$ crystals belong to the baddeleyite-type monoclinic structure with a space group $(\mathrm{P} 2 / 1 / c)$ No. 14 in the International Tables of Crystallography, four molecules per unit cell $(\mathrm{Z}=4)$ and point group symmetry $\left(C_{2 h}^{5}\right)$ [45]. As it can be observed in Fig. 3a, some bonds between the $\mathrm{O}-\mathrm{Zr}-\mathrm{O}$ atoms were projected out of the unit cell. In these unit cells the zirconium $(\mathrm{Zr})$ atoms are coordinated to seven oxygens forming a heptahedron-type polyhedron with the configuration of distorted deltahedral $\left[\mathrm{ZrO}_{7}\right]$ clusters and the prescence of 7 vertices (V), 9 faces (F) and 14 edges (E) composed of eight triangular faces and one square face [5456]. These $\left[\mathrm{ZrO}_{7}\right]$ clusters form irregular polyhedra in the lattice, and for each $\mathrm{ZrO}_{2}$ ceramics we have verified, at different temperatures and times, that the deltahedral $\left[\mathrm{ZrO}_{7}\right]$ clusters exhibit a particular characteristics related to the differences in the $\mathrm{O}-\mathrm{Zr}-\mathrm{O}$ bond angles $[57,58]$. However, in Fig. 3b, it can be noted that $\mathrm{ZrO}_{2}$ crystal belongs to the tetragonal structure with a space group $\left(\mathrm{P}_{2} / \mathrm{nmc}\right)$ No. 137 in the International Tables of Crystallography; two molecules per unit cell $(Z=2)$ and point group symmetry $\left(D_{4 h}^{15}\right)$ [59]. As it can be verified in Fig. 3b and Fig. 3c, some bonds between the $\mathrm{O}-\mathrm{Zr}-\mathrm{O} / \mathrm{O}-\mathrm{Y}-\mathrm{O}$ atoms were projected out of the unit cell. In these unit cells, the $\mathrm{Zr}$ atoms or yttrium (Y) atoms are coordinated to eight oxygens forming a square antiprism-type polyhedron with configuration distorted deltahedral $\left[\mathrm{ZrO}_{8}\right] /\left[\mathrm{YO}_{8}\right]$ clusters and prescence of $\mathrm{V}=8$ vertices, $\mathrm{F}=10$ faces and $E=16$ composed of nine triangular faces and one square face $[60,61]$. These $\left[\mathrm{ZrO}_{8}\right]$ clusters form irregular polyhedra in the lattice and 


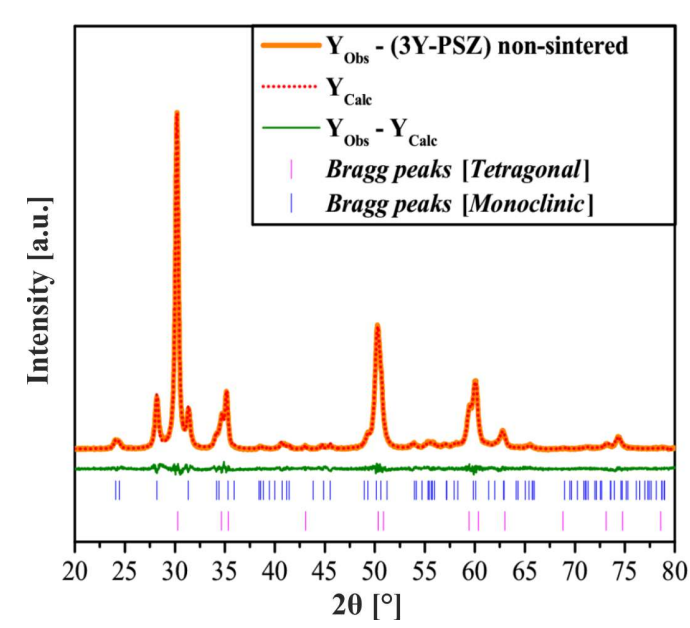

(a)

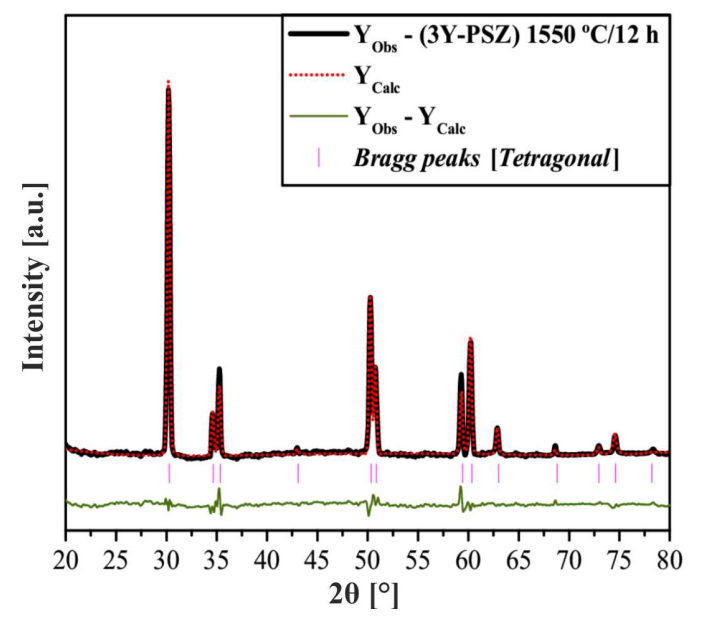

(b)

Fig. 2. (a) Rietveld refinement plot of 3Y-PSZ nonsintered ceramics and (b) 3Y-PSZ ceramics sintered at $1550{ }^{\circ} \mathrm{C}$ for $12 \mathrm{~h}$.

for each $\mathrm{ZrO}_{2}$ or $\mathrm{Y}_{0.03} \mathrm{Zr}_{0.97} \mathrm{O}_{2}$ ceramics we have verified, at different temperatures and times, that the deltahedral $\left[\mathrm{ZrO}_{8}\right] /\left[\mathrm{YO}_{8}\right]$ clusters exhibit a particular characteristics related the differences in the (O-Zr-O/O-Y-O) bond angles [62]. The amount of $\mathrm{V}, \mathrm{E}$ and $\mathrm{F}$ present in the distorted deltahedral $\left[\mathrm{ZrO}_{7}\right] /\left[\mathrm{ZrO}_{8}\right]$ or $\left[\mathrm{YO}_{8}\right]$ clusters, can be confirmed by Euler's polyhedron formula, described by $[\mathrm{V}-\mathrm{E}+\mathrm{F}=2]$.

Fig. 4 shows the electron density models at different planes of 3Y-PSZ non-sintered ceramics (Fig. 4a and Fig. 4b) and 3Y-PSZ ceramics (Fig. 4c and Fig. 4d) sintered at $1550{ }^{\circ} \mathrm{C}$ for $12 \mathrm{~h}$, respectively.

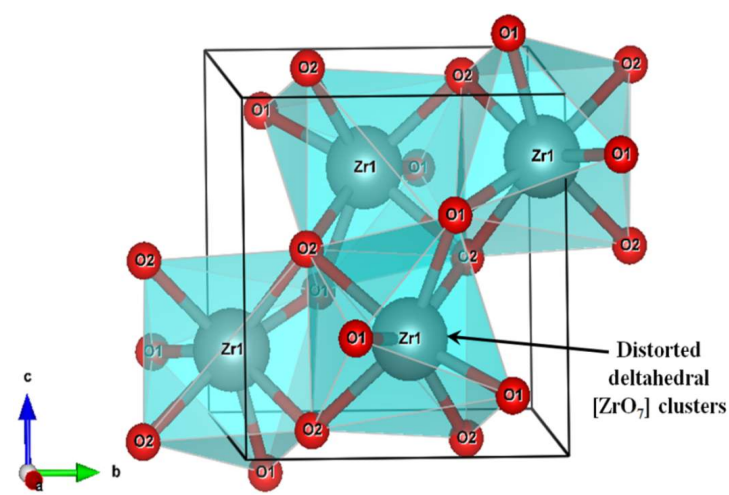

(a)

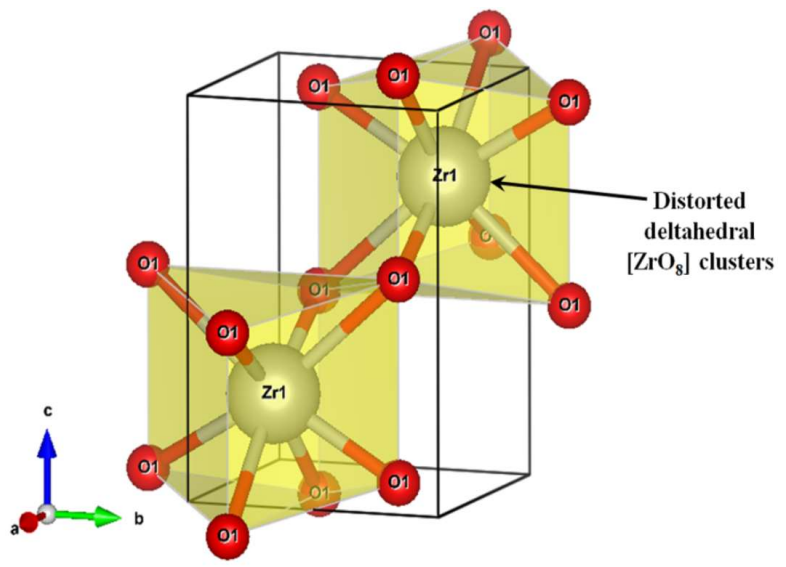

(b)

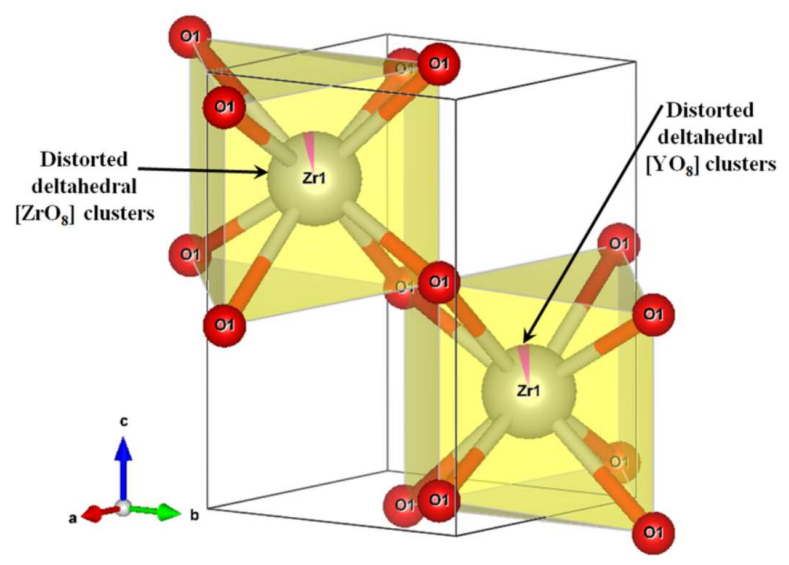

(c)

Fig. 3. (a) Schematic representation of the monoclinic unit cells corresponding to $\mathrm{ZrO}_{2}$ crystal illustrating distorted deltahedral $\left[\mathrm{ZrO}_{7}\right]$ clusters, (b) tetragonal unit cells corresponding to $\mathrm{ZrO}_{2}$ crystal illustrating distorted deltahedral $\left[\mathrm{ZrO}_{8}\right]$ clusters and (c) tetragonal unit cells corresponding to $\mathrm{ZrO}_{2}$ crystals illustrating distorted deltahedral $\left[\mathrm{ZrO}_{8}\right] /\left[\mathrm{YO}_{8}\right]$ clusters, respectively. 


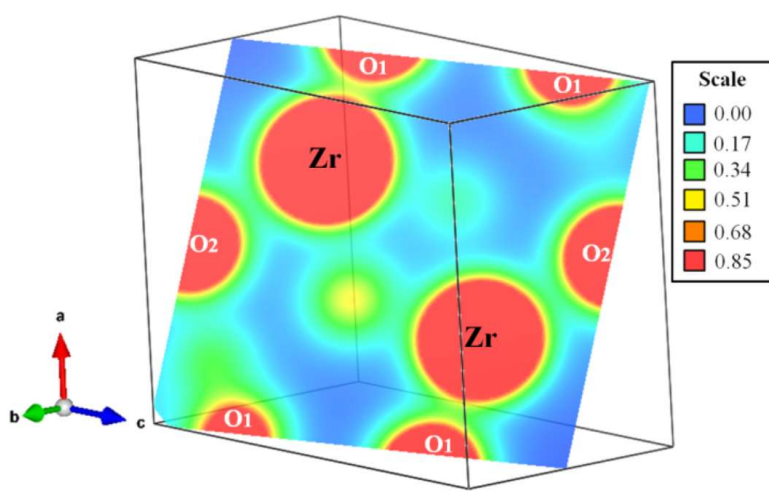

(a)

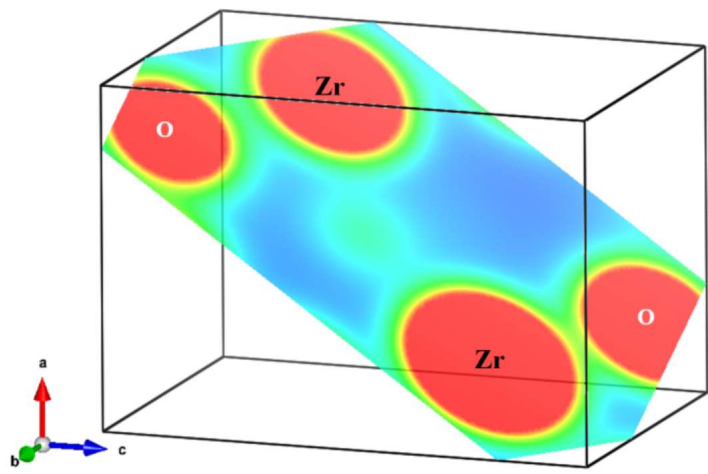

(c)

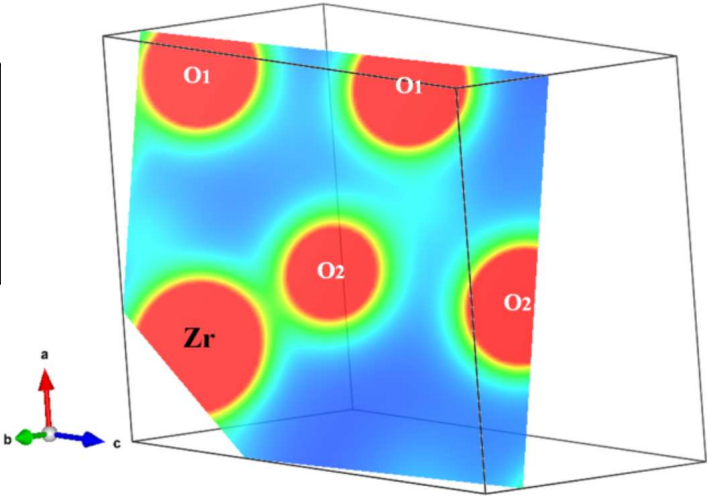

(b)

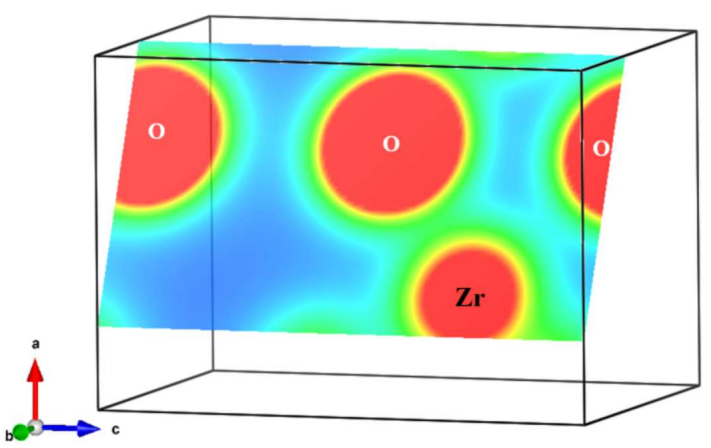

(d)

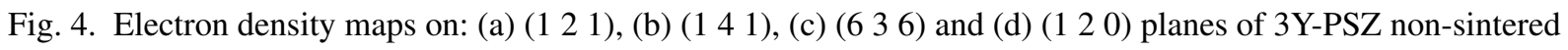
ceramics and ceramics sintered at $1550{ }^{\circ} \mathrm{C}$ for $12 \mathrm{~h}$.

These electron density models were calculated by Fourier transform of structure factors from the structural parameters and atomic scattering factors of free atoms obtained from Rietveld refinement for the non-sintered 3Y-PSZ (Fig. 4a and Fig. 4b) and 3 Y-PSZ ceramics sintered at $1550{ }^{\circ} \mathrm{C}$ for $12 \mathrm{~h}$ (Fig. 4c and Fig. 4d). These data were used in the VESTA program version 3.4.0 [53] to model the electron density map [63]. In these figures, a color scale on each plane is displayed, which demonstrates the zones with high and low electronic densities. In Fig. 4a, the blue colored regions are related to the absence of electronic charge, while the red colored areas exhibit a high electronic density. Moreover, it is possible to verify the presence of two $\mathrm{Zr}$ atoms with high electron density, bonded to two types of $\mathrm{O}$ atoms located at different atomic positions. The $\mathrm{O} 1$ and $\mathrm{O} 2$ atoms exhibit a large atomic displacement, which suggests the existence of distortions in agreement with Fig. 3a. In the (1 $\left.4 \begin{array}{ll}1 & 1\end{array}\right)$ plane shown in Fig. 4b, a large quantity of $\mathrm{O}$ atoms are found and a high amount of blue area suggests that $\mathrm{ZrO}_{2}$ ceramics with monoclinic structure presents oxygen vacancies in the lattice [64]. In Fig. 4c, in (6 3 6) plane it is possible to observe the presence of two $\mathrm{Zr}$ atoms with a high electron density, bonded only by one type of $\mathrm{O}$ atoms due to sintering process of $\mathrm{ZrO}_{2}$ ceramics at $1550{ }^{\circ} \mathrm{C}$ for $12 \mathrm{~h}$ which promotes the phase transformation from monoclinic to tetragonal structure. Moreover, a reduction of blue area related to absence of electronic charge due to presence of $\mathrm{O}$ atoms in $\mathrm{ZrO}_{2}$ ceramics with tetragonal structure can be noted (Fig. 3b nad Fig. 3c). Finally, it is revealed that the $\left(\begin{array}{lll}1 & 2 & 0\end{array}\right)$ plane, is related to presence of several $\mathrm{O}$ atoms that are able to share 
the same $\mathrm{Zr}$ atom with a large bond distance between $\mathrm{O}-\mathrm{Zr}-\mathrm{O}$, which indicates a minor distortion of the $\mathrm{O}-\mathrm{Zr}-\mathrm{O}$ bonds present in $\mathrm{ZrO}_{2}$ ceramics with tetragonal structure (Fig. 4d).

Fig. 5 illustrates the FE-SEM images of 3 Y-PSZ ceramics sintered at $1350{ }^{\circ} \mathrm{C}$ for $4 \mathrm{~h}$, $1350{ }^{\circ} \mathrm{C}$ for $12 \mathrm{~h}, 1550{ }^{\circ} \mathrm{C}$ for $4 \mathrm{~h}$ and $1550{ }^{\circ} \mathrm{C}$ for $12 \mathrm{~h}$, respectively.

A closer examination of the FE-SEM images revealed the effect of processing temperature on the microstructure of the 3Y-PSZ ceramics. As it can be observed in Fig. 5a, when 3Y-PSZ ceramics was sintered at low temperature and short time, a large quantity of pores on the surface could be observed. However, after $12 \mathrm{~h}$ sintering (Fig. 5b) a reduction in quantity of pores and increase in average grain size occurred, which was favored by the matter transport mechanism during the sintering process $[65,66]$. When these 3 Y-PSZ ceramics were submitted to the sintering process performed at $1550{ }^{\circ} \mathrm{C}$ for $4 \mathrm{~h}$ and $12 \mathrm{~h}$, the movement of atoms or molecules was driven by differences in curvature between the grains in contact [67, 68]. In order to reduce surface free energy, atoms supposedly moved from the grains with smaller radius to those with larger radius. Moreover, it is possible that the matter transport between several aggregated particles and the high anisotropy in the grain boundary energies induced the formation of compact and irregular grains (Fig. 5c and Fig. 5d). Finally, the effect of processing temperature on the intensified shrinkage and densification rates resulting in denser mass of the grains was analyzed [69].

FE-SEM images were also of great importance to evaluate the average grain size distribution of different 3 Y-PSZ ceramics sintered at $1350{ }^{\circ} \mathrm{C}$ for $4 \mathrm{~h}, 1350{ }^{\circ} \mathrm{C}$ for $12 \mathrm{~h}, 1550{ }^{\circ} \mathrm{C}$ for $4 \mathrm{~h}$ and $1550{ }^{\circ} \mathrm{C}$ for $12 \mathrm{~h}$, respectively. Hence, the counting of 140 grains was performed to ensure a good statistic response (Fig. 6).

In all cases, the counting of particle sizes was well described by the log-normal distribution as presented in equation 4 [70]:

$$
y=y_{0}+\frac{A}{\sqrt{2 \pi w x}} e^{-\left[\ln \frac{x}{x_{c}}\right] / 2 w^{2}}
$$

where $y_{0}$ is the first value on $y$-axis, $A$ is the amplitude, $\mathrm{w}$ is the width, $\pi$ is a constant, and $\mathrm{x}_{\mathrm{c}}$ is the center value of the distribution curve on $\mathrm{x}$-axis.

The grains of 3Y-PSZ ceramics sintered at $1350{ }^{\circ} \mathrm{C}$ for $4 \mathrm{~h}$ exhibit an average size distribution in the range of $0.11 \mu \mathrm{m}$ to $0.37 \mu \mathrm{m}$ (Fig. 6a). In this system, it was estimated that $42 \%$ of these grains have an average size of approximately $0.18 \mu \mathrm{m}$ and $0.19 \mu \mathrm{m}$. The raise of processing time to $12 \mathrm{~h}$ resulted in an increase in the average grain size to about $0.25 \mu \mathrm{m}$ (23\%) (Fig. 6b) [71]. As can be seen in Fig. 6c, the raise of temperature to $1550{ }^{\circ} \mathrm{C}$ at processing time of $4 \mathrm{~h}$ promoted a considerable increase in grain size ranging from $0.25 \mu \mathrm{m}$ to $0.9 \mu \mathrm{m}$, while $37 \%$ of these grains have an average size of $0.55 \mu \mathrm{m}$. Finally, when the 3Y-PSZ ceramics was sintered at $1550{ }^{\circ} \mathrm{C}$ for $12 \mathrm{~h}$, a considerable increase in average grain size in the range from $0.35 \mu \mathrm{m}$ to $1.25 \mu \mathrm{m}$ was observed (Fig. 6d) which proves the effect of grain growth and it is associated with a high shrinkage rate.

Table 3 shows the measured values for volumetric shrinkage (VS), average grain size (AGS) and hardness (HV) of the sintered bodies in eleven different combinations of temperature and time.

Table 3. Volumetric shrinkage (VS), average grain size (AGS) and Vickers hardness (VH) for all combinations of sintering temperature and times.

\begin{tabular}{|c|c|c|c|}
\hline \multirow{2}{*}{$\begin{array}{c}\text { 3Y-PSZ sintered } \\
\text { ceramics }\end{array}$} & \multicolumn{3}{|c|}{ Measured values } \\
\hline & VS [\%] & AGS $[\mu \mathrm{m}]$ & $\mathrm{VH}[\mathrm{GPa}]$ \\
\hline VII & $44.1 \pm 3.4$ & $0.194 \pm 0.043$ & $5.45 \pm 0.12$ \\
\hline XII & $40.6 \pm 5.4$ & $0.216 \pm 0.053$ & $6.05 \pm 0.22$ \\
\hline $\mathrm{X}$ & $45.0 \pm 5.8$ & $0.228 \pm 0.057$ & $7.49 \pm 0.42$ \\
\hline VIII & $50.2 \pm 5.9$ & $0.276 \pm 0.074$ & $11.3 \pm 0.18$ \\
\hline VI & $50.7 \pm 2.3$ & $0.31 \pm 0.11$ & $13.01 \pm 0.42$ \\
\hline II & $50.3 \pm 2.8$ & $0.384 \pm 0.091$ & $13.27 \pm 0.38$ \\
\hline XI & $50.2 \pm 2.9$ & $0.377 \pm 0.096$ & $13.06 \pm 0.41$ \\
\hline III & $53.1 \pm 5.2$ & $0.454 \pm 0.085$ & $13.71 \pm 0.12$ \\
\hline IX & $54.2 \pm 5.5$ & $0.55 \pm 0.14$ & $13.26 \pm 0.30$ \\
\hline IV & $54.8 \pm 4.2$ & $0.75 \pm 0.19$ & $12.52 \pm 0.32$ \\
\hline $\mathrm{V}$ & $54.8 \pm 1.7$ & $0.54 \pm 0.18$ & $13.24 \pm 0.16$ \\
\hline
\end{tabular}

The data shown in Table 3, were obtained using the CCD method which is able to evaluate 

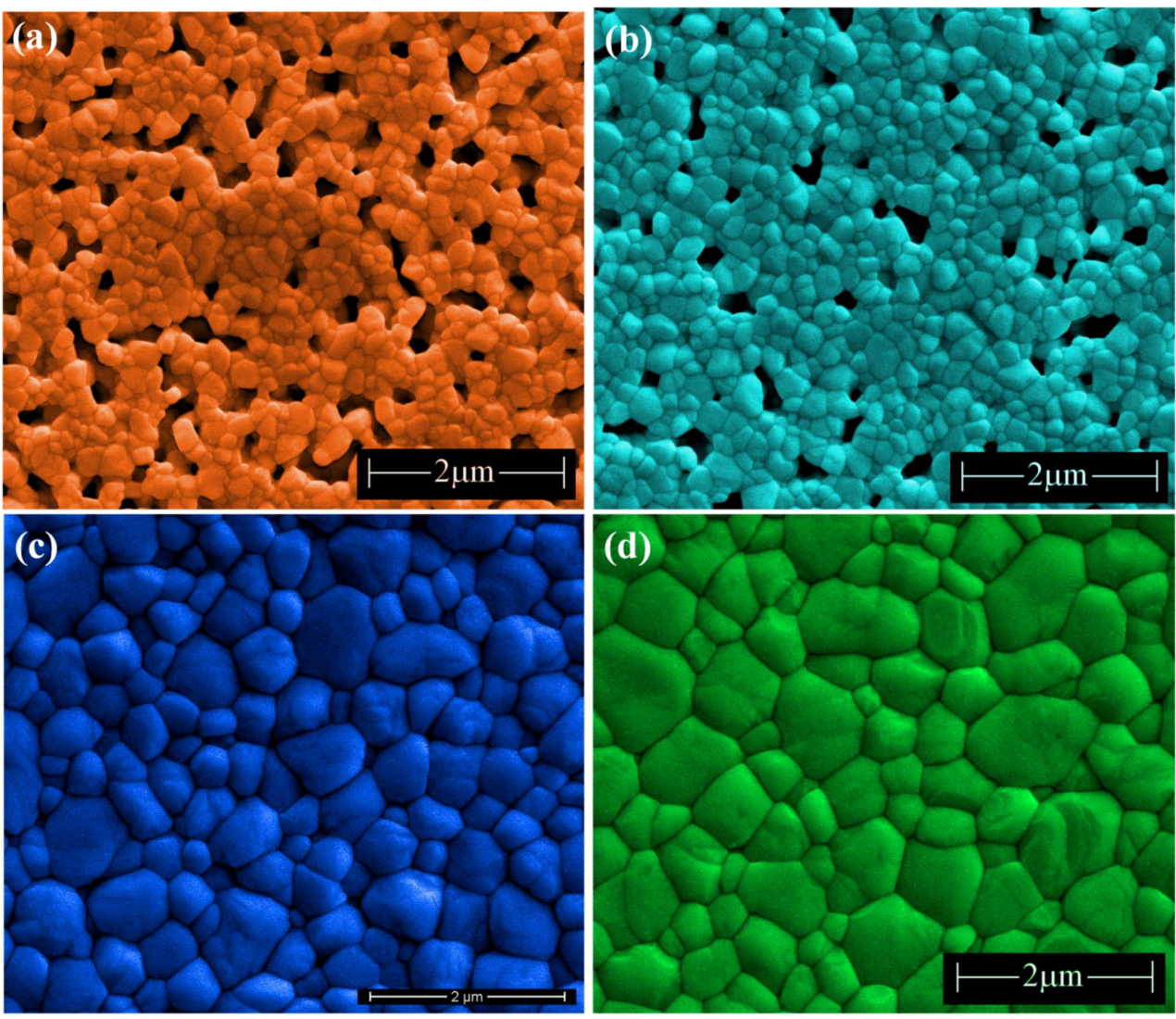

Fig. 5. FE-SEM images for 3 Y-PSZ ceramics sintered at: (a) $1350{ }^{\circ} \mathrm{C}$ for $4 \mathrm{~h}$, (b) $1350{ }^{\circ} \mathrm{C}$ for $12 \mathrm{~h}$, (c) $1550{ }^{\circ} \mathrm{C}$ for $4 \mathrm{~h}$ and (d) $1550{ }^{\circ} \mathrm{C}$ for $12 \mathrm{~h}$.

the volumetric, average grain size and hardness of our 3 Y-PSZ sintered ceramics as presented in equation 5, equation 6 and equation 7, respectively.

$$
\begin{aligned}
V S= & -0.000096385 T^{2}+0.3465594 T \\
& +0.00932161 t^{2}+3.55921 t \\
& -0.00235937 T t-251.158114 \\
A G S= & 0.000001433 T^{2}-0.003428595 T \\
& +0.000797220 t^{2}-0.170456400 t \\
& +0.00011883 T t+2.265139067 \\
V H= & -0.0219377 T^{2}+67.69754 T \\
& -3.66154 t^{2}+273.5638 t \\
& -0.139184 T t-51040.48033
\end{aligned}
$$

where $\mathrm{T}$ is the sintering temperature $\left({ }^{\circ} \mathrm{C}\right)$ and $\mathrm{t}$ is the sintering time $(\mathrm{h})$.
Fig. 7 shows the response surfaces for average grain size, hardness and volumetric shrinkage, respectively.

Fig. 7a shows that volumetric shrinkage increases with the increase of both sintering parameters but the temperature has a more significant effect on the response as compared to the time of processing because the most significant variation occurs in the abscissa. Moreover, as can be observed in Fig. 7a, there is a slight enlargement of the zones of the response surface at higher temperature and longer time conditions. This is an indication that the volumetric shrinkage rate reduces at high sintering temperatures and times [72]. On the surface, for average grain size (Fig. 7b), the temperature effect seems to be slightly more significant. There is a narrowing of the zones with increasing temperature and time, contrary to the former case. This is because in the sintering stage, removing of pores 


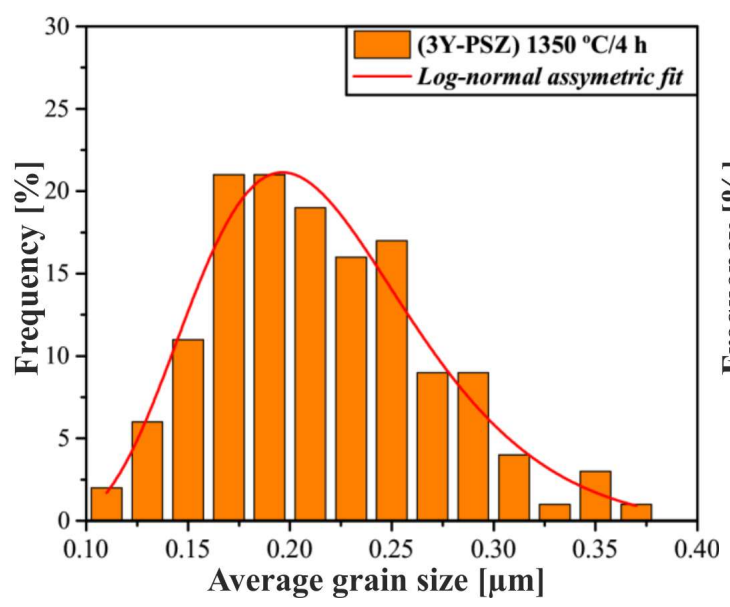

(a)

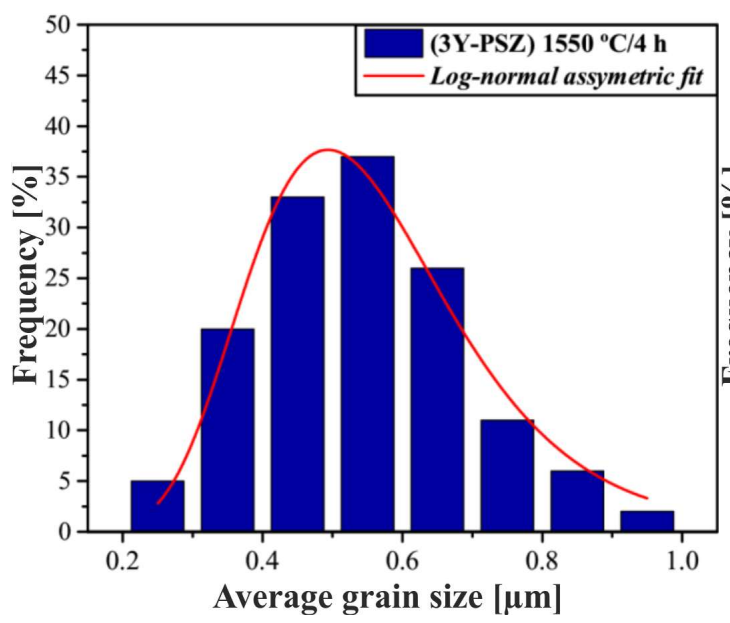

(c)

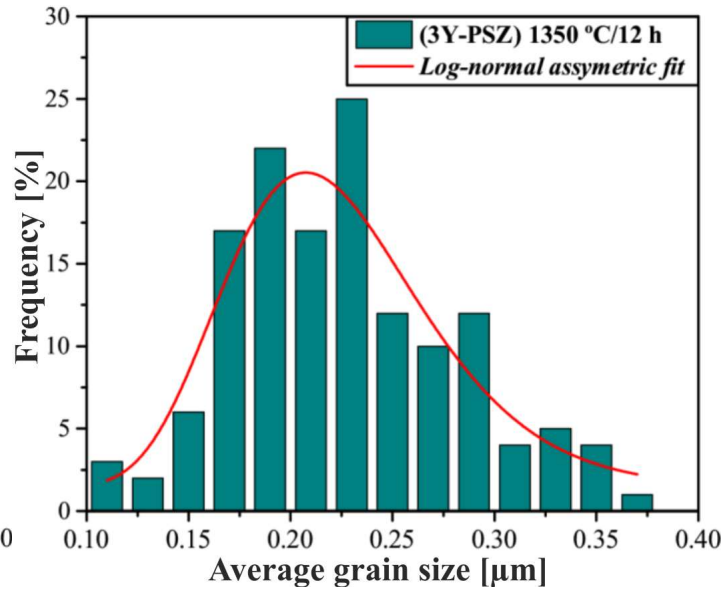

(b)

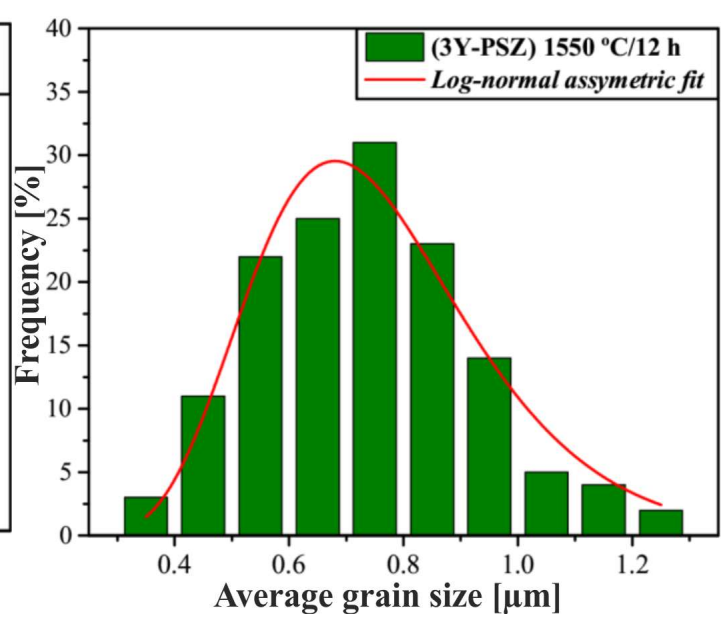

(d)

Fig. 6. Average grain size distribution of 3 Y-PSZ ceramics sintered at: (a) $1350{ }^{\circ} \mathrm{C}$ for $4 \mathrm{~h}$, (b) $1350{ }^{\circ} \mathrm{C}$ for $12 \mathrm{~h}$, (c) $1550{ }^{\circ} \mathrm{C}$ for $4 \mathrm{~h}$ and (d) $1550{ }^{\circ} \mathrm{C}$ for $12 \mathrm{~h}$.

occurs before the stage of grain growth and it is associated with a high shrinkage rate [73]. The response surface to the material hardness (Fig. 7c) also indicates a more significant effect of temperature on the changes in material properties. The closer the maximum of hardness value is the combination of temperature and time (within the darker zone), the lower the hardness increasing rate. The hardness shows the nonlinear behavior as a function of sintering parameters. This occurs because the grain that reached the critical grain size (maximum hardness), makes it more difficult to maintain the stabilized tetragonal phase [74]. It is possible to estimate the value for the critical grain size by combination of Fig. 7c with equation 6. Assuming that the center of the darkest ellipse in Fig. 7c represents the value of maximum hardness of $3 \mathrm{Y}$-PSZ ceramics, this point is close to $\mathrm{T}=1520{ }^{\circ} \mathrm{C}$ for $\mathrm{t}=8 \mathrm{~h}$ and $30 \mathrm{~min}$. Introducing these values into equation 7 , the grain size of $0.509 \mu \mathrm{m}$ was found. This size is within the range reported in the literature $(<0.8)[16,17]$, where a critical grain size for 3 Y-PSZ ceramics of $0.5 \mu \mathrm{m}$ was reported. Introducing the parameters of temperature and time for the critical grain size in equation 6 , the suggested value of maximum hardness $\mathrm{VH}=15.1 \pm 2.3 \mathrm{GPa}$ was obtained. According to equation 5, the predicted volumetric shrinkage in these conditions 


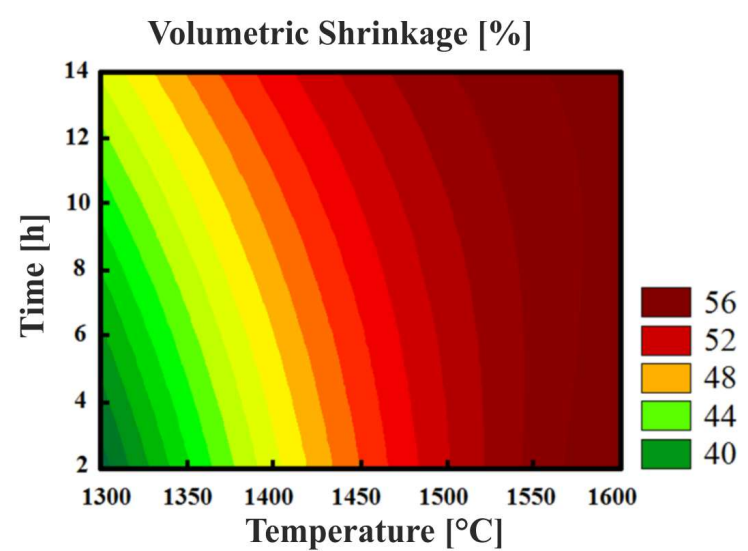

(a)

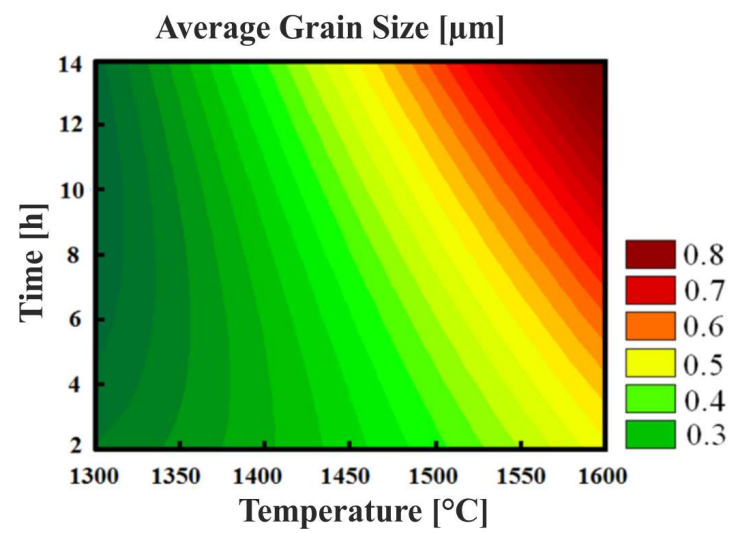

(b)

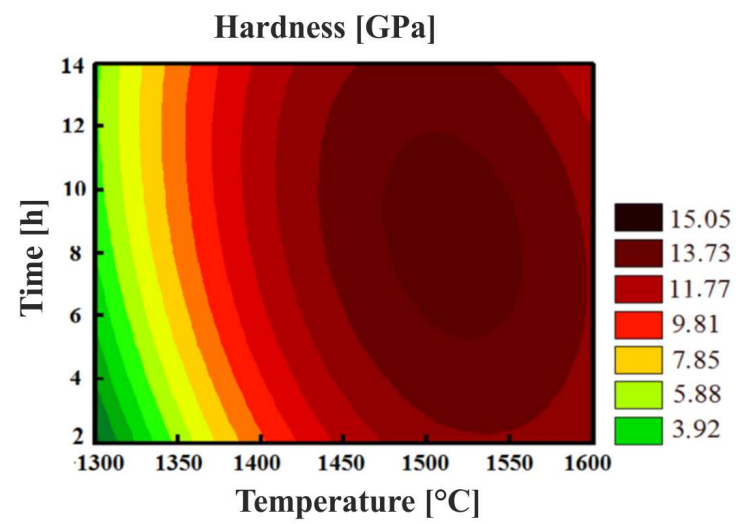

(c)

Fig. 7. Response surfaces of 3Y-PSZ ceramics sintered at different temperatures and times for: (a) volumetric shrinkage, (b) average grain size and (c) hardness.

is $\mathrm{VS}=53.37 \pm 0.08 \%$. A new sample was sintered at $1520{ }^{\circ} \mathrm{C}$ for $8 \mathrm{~h}$ and $30 \mathrm{~min}$ and its properties were characterized. The sample hardness was
$\mathrm{VH}=14.6 \pm 0.2 \mathrm{GPa}$, the average grain size was AGS $=0.51 \pm 0.13 \mu \mathrm{m}$ and the volumetric shrinkage was VS $=53.4 \pm 1.2 \%$. These values are in accordance with the range predicted by the CCD method. Moreover, the literature often points out the hardness between $12 \mathrm{GPa}$ to $13 \mathrm{GPa}$ for $3 \mathrm{Y}$-PSZ ceramics [75-77] and critical grain size $<0.8 \mu \mathrm{m}$ [17], what agrees well with our results presented above.

\section{Conclusions}

In summary, XRD patterns and Rietveld refinement data demonstrate that 3Y-PSZ nonsintered ceramics exhibits two phases related to baddeleyite-type monoclinic structure with a space group $\left(\mathrm{P} 2{ }_{1} / \mathrm{c}\right)$ and the tetragonal structure with a space group $\left(\mathrm{P}_{2} / \mathrm{nmc}\right)$, while $3 \mathrm{Y}-\mathrm{PSZ}$ ceramics sintered from $1450{ }^{\circ} \mathrm{C}$ for $4 \mathrm{~h}$ to $1550{ }^{\circ} \mathrm{C}$ for $12 \mathrm{~h}$ presents a single phase related to tetragonal structure with a space group $\left(\mathrm{P} 4_{2} / \mathrm{nmc}\right)$. Rietveld refinement data were employed to modelling of distorted deltahedral $\left[\mathrm{ZrO}_{7}\right]$ clusters and distorted deltahedral $\left[\mathrm{ZrO}_{8}\right] /\left[\mathrm{YO}_{8}\right]$ clusters of $3 \mathrm{Y}-\mathrm{PSZ}$ non-sintered ceramics and 3Y-PSZ sintered ceramics. Moreover, electron density models were employed to understand the polarization phenomenon and anisotropic atomic displacements in [O-Zr-O] bonds and atomic positions. The sintering variables studied by CCD method provided a detailed analysis of the effect of simultaneous variation of sintering parameters on physical properties of 3Y-PSZ ceramics. CCD method was able to point out the sintering parameters necessary to achieve a critical grain size condition. Measurements of experimental structures prepared in such conditions revealed that the results are in good agreement with the ones suggested by CCD method and the ones presented in the literature.

\section{Acknowledgements}

The authors thank the financial support from the following Brazilian research financing institutions: $\mathrm{CNPq}$ (481288/2011-2; 479644/2012-8; 304531/2013-8 and 402127/2013-7), CAPES, and Programa de Pós-Graduaçăo em Cięncia e Engenharia de Materiais (PPGCEM-UFRN). 


\section{References}

[1] Ali S.A., Karthigeyan S., Deivanai M., Ma R., J. Prosthodont., 34 (2014), 178.

[2] Denry I., Kelly J.R., Dent. Mater., 24 (2008), 299.

[3] Birkby I., Harrison P., Stevens R., J. Eur. Ceram. Soc., 5 (1989), 37.

[4] YANG C.C.T., WeI W.C.J., Wear, 242 (2000), 97.

[5] Kohorst P., Borchers L., Strempel J., Stiesch M., Hassel T., Bach F.W., Hubsch C., Acta Biomater., 8 (2012), 1213.

[6] Christel P., Meunier A., Heller M., Torre J.P., PeILle C.N., J. Biomed. Mater. Res. A, 23 (1989), 45.

[7] Kuwabara M., Ashizuka M., Kubota Y., TsukiDATE T., J. Mater. Sci. Lett., 5 (1986), 7.

[8] Aboushelib M.N., Kleverlaan C.J., Feilzer A.J., J. Prosthodont., 17 (2008), 538.

[9] UoA M., SJoren G., Sundh A., Watari F., Bergman M., Lerner U., Dent. Mater., 19 (2003), 487.

[10] ÖZkol E., Zhang W., Ebert J., Telle R., J. Eur. Ceram. Soc., 32 (2012), 2193.

[11] Muńoz-Tabares J.A., Jiménez-Piqué E., ReyesGasga J., Anglada M., J. Eur. Ceram. Soc., 32 (2012), 3919.

[12] Mazaheri M., Simchi A., Golestani-Fard F., $J$. Eur. Ceram. Soc., 28 (2008), 2933.

[13] Vleugels J., Yuan Z.X., Der Biest O.V., J. Eur. Ceram. Soc., 22 (2002), 873.

[14] Nogiwa-Valdez A.A., Rainforth W.M., Zeng P., Ross I.M., Acta Biomater., 9 (2013), 6226.

[15] Ran S., Vleugels J., Huang S., Vanmeensel K., Blank D.H.A., Winnubst L., J. Eur. Ceram. Soc., 30 (2010), 899.

[16] Chaim R., Mat. Sci. Eng. A-Struct., 486 (2008), 439.

[17] Li J., Tang Z., Zhang Z., Luo S., Mater. Sci. Eng. $B-A d v ., 99$ (2003), 321.

[18] Kim M., Laine R.M., J. Am. Ceram. Soc., 93 (2010), 709.

[19] Sagel-RAnsiJn C.D., Winnubst A.J.A., BurggraAf A.J., VerweiJ H., J. Eur. Ceram. Soc., 17 (1996), 1133.

[20] Theunissen G.S.A.M., Winnubst A.J.A., BurggraAf A.J., J. Eur. Ceram. Soc., 11 (1993), 315.

[21] Asar N.V., Korkmaz T., Gül E.B., Mater. Design., 31 (1993), 2540.

[22] Rasmussen S.T., Ngaji-OKumu W., Boenke K., O'BRIEN W.J., Dent. Mater., 13 (1997), 43.

[23] Wang H., LiaO Y., Chao Y., Liang X., Dent. Mater., 23 (2007), 1108.

[24] Holland T.B., Anselmi-Tamburini U., Quach D.V., Tran T.B., Mukherjee A.K., J. Eur. Ceram. Soc., 32 (2012), 3667.

[25] Raj P.M., Odulena A., Cannon W.R., Acta Mater., 50 (2002), 2559.

[26] Faes A., Fuerbringer J.M., Mohamedi D., Hessler-Wyser A., CABoche G., van Herle J., J. Power Sources, 196 (2011), 7058.
[27] Bashiri M., Geranmayeh A.F., Sci. Iran., 18 (2011), 1600.

[28] Hang Y., QU M., UKKusuri S., Energ. Buildings, 43 (2011), 988.

[29] Hollebeeck S., Borlon F., Schneider Y.J., Larondelle Y., Rogez H., Food Chem., 138 (2013), 1936.

[30] Zhu Z., Zhang G., Luo Y., Ran W., Shen Q., Bioresource Technol., 112 (2012), 254.

[31] Sani E., Mercatelli L., Sans J.L., Sciti D., Sol. Energ. Mat. Sol. C., 140 (2015), 477.

[32] PAN W., Chen K., Ai N., LÜ Z., JiAng S.P., J. Electrochem. Soc., 163 (2016), F106.

[33] Balachandran M., Devanathan S., MuRALEEKRISHNAN R., BHAGAWAN S.S., Mater. Design., 35 (2012), 854.

[34] Guaracho V.V., Kaminari N.M., Ponte M.J., Ponte H.A., J. Hazard. Mater., 172 (2009), 1087.

[35] Fang Y., Zhang Y., Song J., Fan H., Hu L., Mater. Design., 49 (2013), 421.

[36] Diler E.A., IPEK R., Compos. Part B. Eng., 50 (2013), 371.

[37] Pongstabodee S., Monyanon S., LuengNARUEMitChai A., Int. J. Hydrogen. Energ., 37 (2012), 4749.

[38] BAYhan M., ÖNEl K., Mater. Design., 31 (2010), 3015.

[39] Shehzad A., Bashir M.J.K., Sethupathi S., Younus M., LIM J.W., IJPAES., 6 (2016), 255.

[40] Diler E.A., IPEK R., Compos. Part. B. Eng., 50 (2013), 371.

[41] Diler E.A., IPEK R., Mat. Sci. Eng. A-Struct., 548 (2012), 43.

[42] Badwal S., Ciacchi F., Giampietro K., Solid State Ionics, 176 (2005), 169.

[43] Casellas D., Cumbrera F.L., Sánchez-Bajo F., Forsling W., Llanes L., Anglada M., J. Eur. Ceram. Soc., 21 (2001), 765.

[44] ASTM C1327 - 08 Standard Test Method for Vickers Indentation Hardness of Advanced Ceramics.

[45] Smith D.K., NewkiRK W., Acta Crystallogr., 18 (1965), 983.

[46] Bondars B., Heidemane G., Grabis J., LASCHKe K., Boysen H., Schneider J., Frey F., J. Mater. Sci., 30 (1995), 1621.

[47] Hunter B.A., Howard C.J., Kim D.J., Austr. J. Phys., 51 (1998), 539.

[48] Rietveld H.M., J. Appl. Crystallogr., 2 (1969), 65.

[49] Bish D.L., Post J.E., Am. Mineral., 78 (1993), 932.

[50] Bortolotti M., LutTerotti L., Lonardelli I., J. Appl. Crystallogr., 42 (2009), 538.

[51] Lutterotti L., Matthies S., Wenk H.R., Schultz A.J., Richardson J., J. Appl. Phys., 81 (1997), 594.

[52] Lutterotti L., Ceccato R., Dal Maschio R., PaGani E., Mater. Sci. Forum., 278 - 281 (1998), 87.

[53] Momma K., IzUMi F., J. Appl. Crystallogr., 44 (2011), 1272. 
[54] KuZ'Minov Y.S., LOMONOVA E.E., OsiKo V.V., Cubic zirconia and skull melting, Intl. Science Pub, Cambridge, 2008.

[55] Pakharukova V.P., Moroz E.M., Zyuzin D.A., ISHCHENKo A.V., DOLGIKh L.Y., STRIZHAK P.E., J. Phys. Chem. C., 119 (2015), 28828.

[56] Zhang X.J., LiU Z.P., J. Chem. Theory Comput., 11 (2015), 4885.

[57] Kohara S., Salmon P.S., Adv. Phys., 1 (2016), 640.

[58] Zhao X., Vanderbilt D., Phys. Rev. B., 65 (2002), 0751051.

[59] Ikeno H., Krause M., Höche T., Patzig C., Hu Y., Gawronski A., Tanaka I., RÜsse C., J. Phys.Condens. Mat., 25 (2013), 165505.

[60] Yang X., Yang L., Lin S., Zhou R., J. Phys. Chem. $C, 119$ (2015), 6065.

[61] Gaunt A.J., May I., Collison D., Holmana, K.T., Pope M.T., J. Mol. Struct., 656 (2003), 101.

[62] Bai Y., Dou Y., Xie L.H., Rutledge W., Li J.R., Zhou H.C., Chem. Soc. Rev., 45 (2016), 2327.

[63] Cunha F.S., Sczancoski J.C., Nogueira I.C., Oliveira de V.G., Lustosa S.M.C., Longo E., CavalCante L.S., CrystEngComm, 17 (2015), 8207.

[64] Sinhamahapatra A., Jeon J.P., Kang J., Han B., YU J.S., Sci. Rep.-UK, 6 (2016), 27218.

[65] Rahaman M.N., Sintering of Ceramics, CRC Press \& Taylor and Francis Group, New York, 2008.

[66] Badapanda T., Rout S.K., Cavalcante L.S., SCZANCOSKI J.C., PANIGRAhi S., Sinha T.P., Longo E., Mater. Chem. Phys., 121 (2010), 147.
[67] Cheng K., Zhang L., LU C., TieU K., Sci. Rep.-UK, 6 (2016), 25427.

[68] Hosokawa M., Nogi, K., Naito, M., Yokoyama, T.U., Nanoparticle Technology Handbook., Elsevier, Amsterdam, 2008, p. 312.

[69] Badapanda T., Senthil V., Rout S.K., CaVAlCANTE L.S., Simões A.Z., Sinha T.P., PANIGRAHI S., DE Jesus M.M., Longo E., VAREla J.A., Curr. Appl. Phys., 11 (2011), 1282.

[70] Marques V.S., CaValcante L.S., ScZanCoski J.C., Alcântara A.F.P., Orlandi M.O., Moraes E., Longo, E., Varela J.A., SiU Li M., Santos M.R.M.C., Cryst. Growth Des., 10 (2010), 4752.

[71] Fábregas I.O., Reinoso M., Otal E., Kim M., J. Eur. Ceram. Soc., 36 (2016), 2043.

[72] Subbanna M., Kapur P.C., Pradip P., Malghan S.G., Ceram. Int., 27 (2001), 57.

[73] Pouchly V., Maca K., Shen Z., J. Eur. Ceram. Soc., 33 (2013), 2275.

[74] Theunissen G.S.A.M., Winnubst A.J.A., BurggraAf A.J., J. Eur. Ceram. Soc., 11 (1993), 315.

[75] Luo J., Stevens R., Ceram. Int., 25 (1999), 281.

[76] Bundschun W., Gahr K.H.Z., Tribol. Int., 27 (1994), 97.

[77] Marro F.G., Anglada M., J. Eur. Ceram. Soc., 32 (2012), 317.

Received 2016-09-15 Accepted 2017-01-28 